This is the version of the article accepted for publication in Transnational Corporations Review published by Taylor and Francis: https://doi.org/10.1080/19186444.2018.1475105

Accepted version downloaded from SOAS Research Online: http://eprints.soas.ac.uk/26730

\title{
Bank fragility in Africa: GMM dynamic panel data evidence ${ }^{\#}$
}

\author{
Abbi M. Kedir ${ }^{a}$, Syed Faizan Iftikhar ${ }^{b}$, Victor Murinde ${ }^{c}$ and Bernadette Dia Kamgniad \\ aSheffield University Management School, University of Sheffield, Sheffield, UK; \\ ${ }^{b}$ Applied Economics Research Centre, University of Karachi, Karachi, Pakistan; 'School \\ of Finance and Management, SOAS, University of London, London, UK; ${ }^{\mathrm{d} E c o n o m i c}$ \\ Policy Analysis Unit of the CIRES, Abidjan
}

\begin{abstract}
This study investigates the impact of bank-level and macroeconomic variables on bank fragility using a dynamic two-step GMM panel estimator on 433 banks in 46 African countries over the period 1997-2012. The study finds that both bank characteristics and macroeconomic variables are key drivers of bank fragility. The past experience of higher levels of non-performing loans (NPLs) significantly and positively determines current levels of NPLs. The growth of gross loan is negative and significant but economic growth leads to higher NPLs. The equity to assets ratio and the log of assets of banks are negatively associated with NPLs suggesting their potential to provide buffers to banks. Equally, total assets reduce bank fragility. These findings have important policy implications. The study shows that credit risk management initiatives, bank operation oversight and regulations should not be restricted in the times of financial crises, even during positive economic growth episodes in the business cycle.
\end{abstract}

KEYWORDS: Bank characteristics; macroeconomic variables; regulation; NPLs; GMM JEL CLASSIFICATION: G01; G21; G28

\footnotetext{
\# Acknowledgement: Useful comments on previous versions of this paper were provided by seminar participants at the African Development Bank, University of Leicester and University of Birmingham. Murinde wishes to acknowledge funding under the DFID and ESRC funded research project, Grant Ref. ES/N013344/2, as well as the AXA Chair in Global Finance at SOAS University of London. We retain responsibility for all errors.
}

Disclosure statement: No potential conflict of interest was reported by the authors.

CONTACT: Abbi M. Kedir a.m.kedir@sheffield.ac.uk Sheffield University Management School, University of Sheffield, Sheffield, UK 


\section{Introduction}

The assets of banks and other characteristics along with the macroeconomic reality prevailing in a given country, growing financial liberalisation, integration into global financial markets, advances in technology and innovation, a rapid development of new financial products and increasing competition in the banking sector pose significant challenges to financial stability. The recent global financial crisis, which originated in the US, was preceded by a high level of non-performing loans (NPLs) such that substantial bail-outs have had to be invoked to avoid any further dramatic collapse of banks. ${ }^{1}$

The trend in NPLs has led to the collapse of some African banks in recent years. The problem of bad debts in African banks and elsewhere has been a long standing problem for credit risk management teams. Hence, it is important to investigate determinants of non-performing loans by using both bank-specific and country-specific macro variables. Some studies are focus on a single country (e.g. Abid et al., 2014). Fofack (2005) examined the main factors behind high NPLs in Sub-Saharan African countries during the 1990s and uncovers a strong association between NPLs and economic growth, real exchange rate appreciation, real interest rates, interbank loans and net interest margins. The findings highlight the importance of micro and macro-specific determinants. However, the most important driving factors behind NPLs accumulation in Africa relate to macroeconomic volatility such as the deterioration of terms of trade. Our study covers numerous African countries and a large number of banks using recent data from Bankscope and other databases to account for economy wide effects such as movements in the business cycle as captured by the growth of gross domestic product (GDP).

\footnotetext{
${ }^{1}$ See Koutsomanoli-Filippaki (2009); Moshirian (2008) and Tropeano (2010).
} 
The paper is organized as follows. Section 2 will review the relevant literature on NPLs followed by method of analysis in Section 3. Section 4 provides important details of the nature of the data while section 5 discusses the results. Finally, we conclude the paper with potential policy implications on the basis of the preceding analyses.

\section{Related literature}

Using a global database of banks, Iftikhar (2015) has made an important study of bank fragility by examining a range of determining factors such as bank level characteristics, macroeconomic environment, financial reform and bank regulatory or supervision indicators. The study found the significant role that bank specific, macro and financial reform variables play in NPLs. In the current study, we could not control for financial reform and regulatory environments due to the lack of data on those variables. Hence, our review of the relevant empirical literature focuses on the studies that primarily focus on the effect of bank specific and/or macroeconomic variables on NPLs.

Kane and Rice (2001) argue that banking stress depends on the information environment and on the effectiveness of government efforts to regulate/supervise and guarantee bank solvency. Information asymmetry (moral hazard on bank owners and adverse selection on borrowers) is a key factor in bank runs and financial distress in much of Africa. Reducing informational asymmetry has an impact on growth (Murinde, 2012; Ncube and Senbet, 1995). Guy and Lowe (2011) who examine the problem of NPLs in the Barbadian banking system by using bank and macroeconomic variables during the period 1996-2010 and find that both bank-specific and macro variables are crucial to understanding the behaviour of NPLs. Various macroeconomic shocks are applied to the Barbadian banking sector and it is found that high NPLs are associated with different 
macroeconomic stresses. ${ }^{2}$ Shehzad et al (2010) used data on 500 banks from more than 50 countries during 2005-2007 and found that foreign ownership concentration has a negative effect on banks' NPLs but only if the share of ownership is more than $50 \%$. The findings illustrate the importance of non-linearities in the empirical analysis of fragility because some explanatory variables will have effect only after a certain threshold is achieved.

In the same way, along with bank specific variables another strand of the literature has also highlighted the relationship between macroeconomic variables and NPLs. The size, composition and independence of bank board members is critical to the performance of banks, to avoid conflict of interests and agency problem. In Africa, many banks have politicians and former military officials in their boards (e.g. Kenya and Nigeria). Thus, there is no separation of ownership and control (Ncube, 2012). If the interest of board members dictates the decision making process of banks, lending might be reckless and may go to favoured groups. From a policy point of view, the previous of the infiltration of bank boards by special interest groups should be given significant attention by regulatory authorities who are seeking financial stability and effective banks' management in the African context. Lack of separation of bank ownership and control will increase the probability of bad debt and bank distress.

Louzis et al (2012) examined the influence of macro variables on NPLs in the Greek banking sector using panel data. They argued that NPLs can be explained by macroeconomic variables such as real GDP growth, unemployment, interest rates and public debt and found strong effects of these macroeconomic variables on NPLs. Their findings suggested that management quality and inefficiency may be important indicators

\footnotetext{
${ }^{2}$ Another study by Salas and Saurina (2002) includes both microeconomic and macroeconomic variables as determinants of NPLs in the Spanish banking system. They also suggested that any future changes in NPLs can be highly identified by bank-specific variables more in saving than commercial banks.
} 
for predicting future NPLs. Festic et al (2011) studied five new European Union (EU) member states and revealed that the amount of available finance and credit growth may impair banking performance and worsen nonperforming loans due to overheating of economies. Similarly, Espinoza et al (2010) studied the link between macroeconomic variables and NPLs of 80 banks in the Gulf Cooperative Council (GCC) countries. They suggested that high rates of NPLs are generally attributed to high interest rates and adverse macroeconomic conditions. Moreover, other studies, for example Boudriga et al (2010a and 2010b); Berge and Boye (2007); Rinaldi and Sanchis (2006); and Ranjan and Dhal (2003) incorporated macroeconomic determinants as explanatory variables of NPLs. Shen and Chen (2008) also used GDP growth in his paper and found that growth has a significant negative effect on NPLs.

Surprisingly, only few studies investigate the effect of bank specific and country specific variables jointly on NPLs. Our paper considers both bank-specific (micro) and macro variables and their effect on financial fragility which is defined as the ratio of impaired loans to gross loans.

\section{The econometric framework}

As stated above, the main objective of this study is to estimate bank specific and macro level variable enhance or impede the extent and probability of bank/financial fragility in Africa. Here, financial fragility (FF) is the LHS variable which is regressed on the relevant micro (Y) and macro $(\mathrm{X})$ variables. Hence, we have the following general functional set up as a starting point;

$$
F F=f(Y, X)
$$


Basing on equation (1), we specify a dynamic model of financial fragility by introducing a lagged dependent variable of FF. This variable accounts for state/path dependence in NPL accumulation and its inclusion justifies the adoption of the dynamic panel GMM estimation technique (Arellano and Bond, 1991; Blundell and Bond, 1998) as reflected in equations (2). This inclusion of the lag of the dependent variable renders the OLS estimation technique inconsistent and biased. To address the potential problem of endogeniety that is introduced due to the lagged LHS variable and the possibility of correlation between any right hand side variable of the model with error term $\left(\xi_{i, j, t}\right)$ of bank $\mathrm{i}$, country $\mathrm{j}$ and year/time $\mathrm{t}$, we adopted a dynamic two-step system GMM panel estimator technique instead of one-step GMM. This is due to the fact that dynamic twostep system GMM is asymptotically more efficient and suitable for analysis than onestep. ${ }^{3}$ We employ the Windmijer (2005) finite sample correction (which provides WCrobust standard errors) to compensate for the downward biased in standard errors generated by two-step GMM estimates. In the Blundell and Bond GMM estimator, there is no correlation between the difference of disturbance term $\left(\Delta \xi_{i, j, t}\right)$ of the model and the higher order lags of level variables. Similarly, the disturbance term $\left(\xi_{i, j, t}\right)$ is not correlated with the lag difference of these variables. The assumption of moment conditions in the two-step GMM are applicable for each t. The basic intuition of the Blundell and Bond estimator is that the lagged values of the regressor are used as instruments for right hand side variables. In addition, by taking first differences, the unobserved fixed effects are eliminated in the estimating equation and the regression in levels and in first differences are estimated simultaneously. Along with the Sargan test statistic, we report statistics related to first-order autoregression [AR (1) or] and second-order autoregression [i.e.AR

\footnotetext{
${ }^{3}$ Baltagi (2001) documented that in a dynamic relationship, fixed effect or random effect estimation techniques provide biased and inconsistent estimates, particularly when $\mathrm{N}$ is quite larger than $\mathrm{T}$; normally a fixed and random effect estimation technique applies in a static relationship.
} 
(2)] to gauge the presence of serial correlation in disturbance term $\left(\xi_{i, k, t}\right)$. It is assumed that $\xi_{i, k, t}$ in Blundell and Bond's estimator is an independent idiosyncratic error term, so as a technical requirement the first order AR (1) test should reject the null hypothesis (Ho $=$ No Autocorrelation), while the second order AR (2) test should not reject the hypothesis of no or zero correlation. Identification is an important consideration in the presence of lagged dependent varaibles and conventionally, the Sargan test of over-identifying restriction is used to test the validity of the instruments in the model. If the null hypothesis cannot be rejected under Sargan, it suggests that over-identifying restrictions or instruments used are valid.

In equation (2), we introduce financial reform as the main explanatory variable and analyze its impact on financial fragility. Thus, in order to estimate the financial fragility of banks, we consider the standard model used in empirical studies (See Louzis et al, 2012; Merkl and Stolz, 2009; and Salas and Saurina, 2002). A dynamic panel variant of the model is specified in the following way:

$$
F_{i, j, t}=\alpha_{0}+\alpha_{1} F_{i, j,(t-1)}+\alpha_{2} Y_{i, j, t}+\alpha_{3} X_{j, t}+\mu_{i, j}+\xi_{i, j, t}
$$

where $\boldsymbol{F F}{ }_{i, j, t}$ is the financial fragility indicator of bank $\boldsymbol{i}$ in country $\boldsymbol{j}$ at time $\boldsymbol{t} . \boldsymbol{F F} \boldsymbol{i , j , t - \boldsymbol { I }}$ is its lagged value and is entered to capture the speed of adjustment to a steady state/

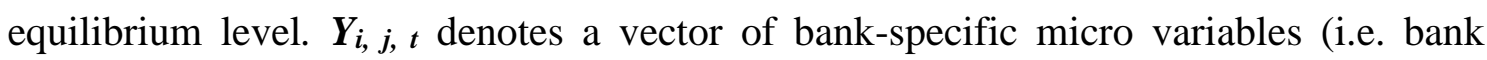
efficiency, equity to assets ratio, the lag value of growth of gross loans and log of total assets); $\boldsymbol{X}_{j, t}$ represents a vector of the macroeconomic variables (i.e. real GDP growth, GDP deflator and the unemployment rate); $\boldsymbol{\mu} i, j$ controls the variant behaviour of fixed characteristics of banks (or bank heterogeneity) and $\xi_{i, j, t}$ is the independently and identically distributed (iid) disturbance term, which contains all factors that cannot be observed by the researcher. 


\section{Data}

In this paper micro-panel data of 433 banks in 46 African countries has been used over the period 1997-2012. The total raw data from these countries during the sample period 1997 to 2012 contains 2484 observations from 539 banks. After making data checks, and re-examining data issues such as missing observation, inconsistencies and reporting errors of data, the final data set used for estimation consists of 1840 observations that includes 433 individual-banks.

The data of bank-specific and macroeconomics-specific variables come from different sources. The data on bank-specific variables such as: Bank/Financial Fragility (proxied by Impaired Loans to Gross Loan), Bank Size (proxy of Total Assets), Growth of Gross Loans, Bank Capital (proxy of Equity to Asset Ratio) and Bank Efficiency (proxy of Cost to Income Ratio) has been collected from the Orbis (Bank-scope) database maintained by Fitch/IBCA/Bureau Van Dijk, which is a key data source for financial fragility studies. Similarly, the data on macroeconomics variables, namely GDP growth and GDP deflator has been taken from the World Development Indicators (WDI) database maintained by the World Bank. Lastly, the outliers from the data set are removed in order to reduce their potential biased effect on estimated coefficients.

\subsection{Financial Fragility}

"In macroeconomics, the term financial fragility is used loosely to refer to a financial system's susceptibility to large-scale financial crises caused by small routine shocks" (Lagunoff and Schreft, 2001:220). In this paper the ratio of impaired loans to gross loan (i.e. the accounting term for NPLs) is used as a proxy for financial fragility. The ratio of impaired loans to gross loans based on the amount of loans which are classified by banks as impaired or doubtful. The lower the value of the ratio, the better the asset quality or vice versa. In related work, Iftikhar (2015), Shehzad et al (2010) and Shen and Chen 
(2008) also employed NPLs as a proxy of banking fragility to measure the riskiness of banks.

\subsection{Bank size}

To examine the effect of the size of bank on financial fragility, the log of total assets is included in the model. The sign of bank size is expected to be negative on financial fragility because big size banks are more capable or equipped in credit risk management strategies, and have enough resources to deal with defaulters. While, Mishkin (2006) and Kane (2000) documented that the "too big to fail" effect in large size of banks can also be the main reason of higher risk taking.

\subsection{Bank capital}

To measure the level of banks' capitalisation, the equity to asset ratio has been used. This ratio also indicates the bank's capability and credit worthiness to compensate any kind of losses. The higher equity to asset ratio, the stronger banks capitalisation which suggests stronger security of banks and lower likelihood of bank defaults.

\subsection{Growth of gross loans}

Using the growth of gross loan, we examine the riskiness of banks in African countries. If this growth rate indicates excessive loan growth in the economy (e.g. due to overinflationary effects), it can be a symptom of deteriorating underwriting standards. We expect that loan growth leads to increased probability of financial fragility in the short run. Hence, the lag value of loan growth is included in the regression to assess the impact of speed of growth of gross loan on likelihood of building NPLs. Finding of previous studies suggest that the relation between financial fragility and loan growth is positive, because rapid loan growth and a possible decline in loan quality during contractionary time could deteriorate the monitoring and evaluating ability of banks which leads to enhance the size of bad debts (see Clair, 1992). 


\subsection{Bank efficiency}

Cost to income ratio is used as a proxy of bank efficiency to measures the efficiency and overheads of the respective banks. The lower (higher) the ratio, the better (worse) the efficiency, which suggested that efficient and well organized banking system could reduce the likelihood of loan default.

\subsection{Macroeconomic variables}

Number of existing studies in banking and finance literature has used macro-specific determinants to examine their impact on financial fragility. The finding of these studies show that financial fragility is closely associated with the health of the macroeconomy. For instance, Salas and Surina (2002); Fofack (2005) and Espinoza and Prasad (2010) used GDP growth rate and real GDP per capita growth, respectively. Their finding revealed that unfavourable macroeconomic conditions or recession phase worsen the banking sector performance by increasing the amount of non-performing loans (NPLs).

\section{Discussion of results}

\subsection{Descriptive statistics}

The summary statistics of our variables is provided in table 1 below. All variables are in percentage terms except log of total assets, which is in millions of USD. The mean value of the financial fragility is estimated to be $11.7 \%$ and ranges from 0 to $150 \%$. The average ratio of impaired loans to gross loans is very high in Africa by international standards (Baltagi, et al 2011). Particularly the upper limit of this ratio given by the maximum value reported in the tables is much higher than an international average of about $86.9 \%$ reported in Iftikhar (2015). This points to the need to pay careful attention to the accumulation of bad debts in African banks. The average of the log of total assets is 5.78 million USD which is lower than the international average of about 6.14 million USD, 
the variable ranging from -3.72 to 12.21 million USD. The growth of gross loans is $34.97 \%$ which is much higher than the global average $18.72 \%$ calculated by Iftikhar (2015). This indicates the higher pace of accumulation of doubtful loans in Africa increasing the likelihood of bank fragility happening. Similarly, the average ratio of equity to assets is around is $14.2 \%$ compared to a global figure of $17.01 \%$ including the lower capitalization rates prevailing in African banks. The mean value of cost to income ratio is $62 \%$ approximately and this does not compare well with the international level of CIR which is $57.1 \%$. Since cost to income ratio was used as a proxy for bank efficiency, the higher rates of CIR in African banks indicates their relative inefficiency relative to their international peers. In addition to the bank-specific variables, we have two macroeconomic variables. The mean growth rate of GDP is $4.72 \%$ indicating the healthy macroeconomic economic growth in Africa in recent years (esp. since 2000) as far as GDP is concerned. The average rate of the GDP deflator is 228.65 and ranges from 0 to 3868.3. This variable is an annual indicator of the GDP implicit deflator which is the ratio of GDP in current local currency to GDP in constant local currency. The base year varies by country. It reflects price changes for total GDP. As the most general measure of the overall price level, it accounts for changes in government consumption, capital formation (including inventory appreciation), international trade, and the main component, household final consumption expenditure. 
Table 1: Summary statistics of key variables ${ }^{4}$

\begin{tabular}{|l|l|l|l|l|l|}
\hline Variable & Mean & Std dev & Min & Max & N \\
\hline $\begin{array}{l}\text { Financial Fragility } \\
(\%)\end{array}$ & 11.66 & 14.1 & 0 & 150 & 2484 \\
\hline $\begin{array}{l}\text { Growth of gross loan } \\
(\%)\end{array}$ & 34.97 & 64.36 & -78.67 & 952.42 & 2484 \\
\hline $\begin{array}{l}\text { Equity to Asset } \\
\text { Ratio (\%) }\end{array}$ & 14.16 & 12.93 & -179.2 & 99.86 & 2484 \\
\hline $\begin{array}{l}\text { Log of total assets } \\
\text { (Million USD) }\end{array}$ & 5.78 & 1.87 & -3.73 & 12.2 & 2484 \\
\hline $\begin{array}{l}\text { Cost-to-Income } \\
\text { Ratio (\%) }\end{array}$ & 62.04 & 27.31 & 4.4 & 372.1 & 2484 \\
\hline Growth of GDP (\%) & 4.72 & 3.73 & -16.9 & 37.9 & 2484 \\
\hline \begin{tabular}{l} 
GDP Deflator \\
\hline
\end{tabular} & 228.65 & 401.42 & 0 & 3868.3 & 2484 \\
\hline
\end{tabular}

In addition to the above summary statistics, we also examine the correlation between the bank fragility variable and the explanatory variables. The results indicate that all the correlations are statistically significant at the $5 \%$ level. It is important to note that the correlation between the growth of gross loan, log of total assets, cost-to-income ratio and financial fragility are relatively stronger than the correlations with other explanatory variables. The pair-wise correlation matrix also explains that the growth of gross loans, the $\log$ of total assets, equity to assets ratio and growth of gross domestic product (GDP)

${ }^{44}$ The details of the names of the countries and bank characteristics by country can be obtained from the authors upon request. 
are negatively correlated with financial fragility while the correlations between financial fragility and cost-to-income ratio is positive.

\subsection{Effect of micro and macro variables on bank fragility in Africa}

The dynamic GMM coefficient estimates of fragility of 433 African banks in 46 countries for the period 1997 to 2012 are given in tables 2 . The equity to assets ratio and lagged value of financial fragility are treated as endogenous variables whereas the bank efficiency variable is treated as predetermined variable, meaning that "GMM style" instruments are used. The lagged dependent variable and bank efficiency variable are instrumented by their lags in all regressions. The results of Wald chi square and the pvalues of the Sargan test and AR (2) are significant at least at 5\% level, which suggests that the null hypothesis of valid over-identifying instruments and the presence of $2^{\text {nd }}$ order serial correlation [(i.e. AR (2)] cannot be rejected. These diagnostic tests provide evidence of the appropriateness/validity of instruments used.

Table 2 reports the results based on the estimation of equation 1, in which financial fragility has been regressed on bank-specific and macro-specific variables. The lagged dependent variable is positive and highly significant at the $1 \%$ level. This means bank fragility is state dependence or the fragility of the banking system in the previous year ( $\mathrm{t}$ 1) exacerbates current bank/financial fragility (t). The equity to assets ratio and log of total assets have coefficients that are negative and statistically significant at the 5\% level respectively. The findings on theses variables show that an increase in bank capital stock and size of banks reduces the chance of financial fragility by -0.41 and -7.96 percentage points, respectively. The result of the log of total assets is also consistent with the findings of Salas and Saurina (2002) and Fernandez de Lis et al. (2000) who found a negative 
relationship between bank size and NPLs. This suggests that bigger banks provide more diversification opportunities. The coefficient of growth of gross loans is negative and significant at the $10 \%$ level, which implies that high growth of loans reduces fragility of banks. This is unexpected and contrasts with the findings of Espinoza and Prasad, 2010). An interesting observation is the result pertaining to the speed of growth of the size of the macroeconomy as captured by the growth of GDP. There is a positive and significant association between economic growth and bank fragility. Though unexpected it is plausible to say that financial difficulties of banks are not only observed during economic decline, but they can also be experienced during times of boom as demonstrated in our finding. Therefore, credit risk management and careful assessment of the health of the financial system should not be ignored when economies are on the positive growth trajectory.

Table 2: Dynamic panel estimation of fragility in African banks

\begin{tabular}{|c|c|}
\hline Variables & $\begin{array}{c}\text { Coefficient } \\
\text { (WC-Robust standard error) }\end{array}$ \\
\hline Financial fragility $(\mathrm{t}-1)$ & $\begin{array}{l}\text { 0. 451**** } \\
(0.083)\end{array}$ \\
\hline Cost to income ratio & $\begin{array}{l}0.042 \\
(0.028)\end{array}$ \\
\hline Equity to assets ratio(t-1) & $\begin{array}{l}-\mathbf{- 0 . 4 1 0 * * *} \\
(0.174)\end{array}$ \\
\hline Growth of gross loans & $\begin{array}{l}-0.019 * \\
(0.010)\end{array}$ \\
\hline Log of total assets & $\begin{array}{r}-7.954 \\
(2.865)\end{array}$ \\
\hline Growth of GDP & $\begin{array}{l}0.224 * * \\
(0.112)\end{array}$ \\
\hline GDP implicit deflator & $\begin{array}{c}-0.011 \\
(0.081) \\
\end{array}$ \\
\hline No. of banks & 433 \\
\hline Wald Chi square (p-value) & $\begin{array}{l}188.2 \\
(0.00)\end{array}$ \\
\hline Sargan test statistic (p-value) & $\begin{array}{l}204.9 \\
(0.25)\end{array}$ \\
\hline
\end{tabular}




\begin{tabular}{|l|c|}
\hline \multirow{2}{*}{$\mathrm{AR}(1)$ test statistic (p-value) } & -3.86 \\
& $(0.00)$ \\
\hline \multirow{2}{*}{$\mathrm{AR}(2)$ test statistic (p-value) } & 0.08 \\
& $(0.93)$ \\
\hline
\end{tabular}

Note:

The dependent variable is financial fragility, which is considered as a proxy of impaired loans to gross loans. Equity to assets ratio and lagged value of impaired loans to gross loans are treated as endogenous. The lagged dependent variable is instrumented by its lagged value. Cost to income ratio treated as predetermine variable and instrumented by its lagged value. All regressions include a full set of time dummies but results are not reported in the table. Figures in parenthesis are robust standard errors obtained by the Windmeijer WC-robust estimator.

(***) Coefficients are statistically significant at the $1 \%$ level.

(**) Coefficients are statistically significant at the 5\% level.

(*) Coefficients are statistically significant at the $10 \%$ level.

\section{Conclusion}

The recent waves of banking crises globally and the collapse of some African banks have been predominantly attributed to a high ratio of loan default. The purpose of this study is to explore the impact of micro and macro-economic factors on bank/financial fragility in Africa. We examined the key drivers of financial fragility of 46 African countries using bank-level data for a sample of 433 banks during the period 1997-2012. We found that the financial vulnerability of banking sector is significantly affected both by bank-specific and macro-specific variables. Bank size and capitalization are critical to maintain a healthy financial system in the continent. The importance of keeping a supervisory oversight on banks at times when there is a positive economic growth should not be emphasized enough. The results of this paper indicate that credit risk management and careful assessment of the health of the financial system should not be ignored when economies are on the positive growth trajectory. Ex-post treatment of financial fragility should not be the norm. For effective supervision, control and management of banks, policy makers should plan for rainy days when times are good. This is because the 
regression results highlight the increase in NPLs during positive macroeconomic episodes. Related research pointed out that strong and sound banking regulation and supervision have an inverse relationship with financial fragility (Iftikhar, 2015). We believe that the problem of accumulation of NPLs in Africa could be mitigated greatly if 1) the banking system of African countries implement effective and sound international practices that affect banking supervision and regulation policies to ensure the financial stability; 2) transparent and accountable systems are installed in place to improve screening and monitoring clients that can enable banks to have some control over the thorny issues of moral hazard and adverse selection (asymmetric information) (Stiglitz and Weiss, 1983), and $\mathrm{m}$; 3) if policy makers show commitment to eliminate the influence of politically exposed personalities (PEPs) in bank boards, ownership and operations to limit state capture or rent-seeking behavior; ; and 4) if providing adequate resources to credit manager for properly organizing the loan. 


\section{References}

Abid, L., Ouertani, M., \& Zouari-Ghorbel, S. (2014). Macroeconomic and bank-specific determinants of household's non-performing loans in Tunisia: A dynamic panel data. Procedia Economics and Finance, 13, 58-68. doi:10.1016/S22125671(14)00430-4

Andrianova, S., Baltagi, B.H., Demetriades, P.O., \& Fielding, D. (2010). The African credit trap (pp. 1-31). Leicester, UK: University of Leicester. Working Paper No. $10 / 18$.

Arellano, M., \& Bond, S. (1991). Some tests of specification for panel data: Monte Carlo evidence and an application to employment equations. The Review of Economic Studies, 58, 277-297. doi:10.2307/2297968

Baltagi, B.H. (2001). Econometric analysis of panel data (2nd ed.). Chichester: John Wiley and Sons.

Berger, T.O., \& Boye, K.G. (2007). An analysis of bank's problem loans. Norges Bank Economic Bulletin, 78, 65-76.

Blundell, R., \& Bond, S. (1998). Initial conditions and moment restrictions in dynamic panel data models. Journal of Econometrics, 87, 115-143. doi:10.1016/S03044076(98)00009-8

Boudriga, A., Taktak, N.B., \& Jellouli, S. (2010a). Bank specific, business and institutional environment determinants of banks nonperforming loans: Evidence from MENA countries. Economic Research Forum Working Paper No. 547.

Boudriga, A., Taktak, N.B., \& Jellouli, S. (2010b). Bank supervision and nonperforming loans: A cross-country analysis. Journal of Financial Economic Policy, 1, 286318. doi:10.1108/17576380911050043

Clair, R.T. (1992). Loan growth and loan quality: Some preliminary evidence from Texas banks. Economic and Financial Policy Review, 3, 9-22.

Demetriades, P.O., Baltagi, B.H., \& Andrianova, S. (2011). Loan defaults in Africa. Leicester, UK: University of Leicester. Working Paper \# 11/36.

Espinoza, R.A., \& Prasad, A. (2010). Nonperforming loans in the GCC banking system and their macroeconomic effects (pp. 1-24). IMF: Washington, DC. IMF Working Papers, WP/10/224. 
Fernandez De Lis, S., Pages, J.M., \& Saurina, J. (2001). Credit growth, problem loans and credit risk provisioning in Spain (pp. 331-353). Bank For International Settlement, BIS Papers No. 1.

Festic, M., Kavkler, A., \& Repina, S. (2011). The macroeconomic sources of systemic risk in the banking sectors of five new EU member states. Journal of Banking \& Finance, 35, 310-322. doi:10.1016/j.jbankfin.2010.08.007

Fofack, H. (2005). Nonperforming loans in sub-Saharan Africa: Causal analysis and macroeconomic implications. Washington D.C.: The World Bank. World Bank Policy Research Working Paper No. 3769.

Guy, K., \& Lowe, S. (2011). Nonperforming loans and bank stability in Barbados. Economic Review, 37, 77-99.

Iftikhar, S.F. (2015). Financial reforms and financial fragility: A panel data analysis. International Journal of Financial Studies, 3, 84-101. doi:10.3390/ijfs3020084

Kane, E.J. (2000). Incentives for banking megamergers: What motives might regulators infer from event-study evidence? Journal of Money, Credit and Banking, 32, 671-701. doi:10.2307/2601202

Kane, E.J., \& Rice, T. (2001). Bank runs and banking policies: Lessons for African policy makers. Journal of African Economics, 10, 36-71. doi:10.1093/jae/10.Suppl1.36

Koutsomanoli-Filppaki, A., \& Mamatzakis, E. (2009). Performance and Merton-type default risk of listed banks in the EU: A panel VAR approach. Journal of Banking \& Finance, 33, 2050-2061. doi:10.1016/j.jbankfin.2009.05.009

Lagunoff, R., \& Schreft, S.L. (2001). A model of financial fragility. Journal of Economic Theory, 99, 220-264. doi:10.1006/jeth.2000.2733

Louzis, D.P., Vouldis, A.T., \& Metaxas, V.L. (2012). Macroeconomic and bankspecific determinants of non-performing loans in Greece: A comparative study of mortgage, business and consumer loan portfolios. Journal of Banking \& Finance, 36, 1012-1027. doi:10.1016/j.jbankfin.2011.10.012

Merkl, C., \& Stolz, S. (2009). Banks' regulatory buffers, liquidity networks and monetary policy transmission. Applied Economics, 41, 2013-2024. doi:10.1080/00036840802360245

Mishkin, F.S., Stern, G., \& Feldman, R. (2006). How big a problem is too big to fail? A review of Gary Stern and Ron Feldman's “Too Big To Fail: The Hazards of 
Bank Bailouts". Journal of Economic Literature, 44, 988-1004.

doi:10.1257/jel.44.4.988

Moshirian, F. (2008). Globalisation, growth and institutions. Journal of Banking \& Finance, 32, 472-479. doi:10.1016/j.jbankfin.2007.10.002

Murinde, V. (2012). Financial development and economics growth: Global and African evidence. Journal of African Economies, 21, i10-i56. doi:10.1093/jae/ejr042

Ncube, M. (2012). South African corporate governance, Oxford companion of African economics. Oxford: Oxford University Press.

Ncube, M., \& Senbet, L. (1994). Perspectives on financial regulation and liberalization in Africa under incentive problems and asymmetric information. Nairobi: AERC. AERC Discussion Paper.

Ranjan, R., \& Dhal, S.C. (2003). Non-performing loans and terms of credit of public sector banks in India: An empirical assessment. Reserve Bank of India Occasional Papers, 24, 81-121.

Rinaldi, L., \& Sanchis-Arellano, A. (2006). Household debt sustainability: What explains household non-performing loans? An empirical analysis. European Central Bank: Frankfurt. ECB Working Paper No. 570.

Salas, V., \& Saurina, J. (2002). Credit risk in two institutional regimes: Spanish commercial and saving banks. Journal of Financial Services Research, 22, 203224. doi:10.1023/A:1019781109676

Shaban, M., \& James, G. (2018). The effects of ownership change on bank performance and risk exposure: Evidence from Indonesia. Journal of Banking and Finance, 48, 483-497. doi:10.1016/j.jbankfin.2017.02.002

Shehzad, C.T., DeHaan, J., \& Scholtens, B. (2010). The impact of bank ownership concentration on impaired loans and capital adequacy. Journal of Banking and Finance, 34, 399-408. doi:10.1016/j.jbankfin.2009.08.007

Shen, C., \& Chen, C. (2008). Causality between banking and currency fragilities: A dynamic panel model. Global Finance Journal, 19, 85-101. doi:10.1016/j.gfj.2007.11.003

Stiglitz, J., \& Weiss, A. (1983). Alternate approaches to the analysis of markets with asymmetric information. American Economic Review, 73, 246-249.

Tropeano, D. (2010). The current financial crisis, monetary policy and Minsky's structural instability hypothesis, mimeo, Dipartimento di Istituzioni Economiche e Finanziarie, Universita Degli Studi Macerata, Italy. 
Windmeijer, F. (2005). A finite sample correction for the variance of linear efficient two-step GMM estimators. Journal of Econometrics, 126, 25-51. doi:10.1016/j.jeconom.2004.02.005 